Article

\title{
Business Group-Affiliation and Corporate Social Responsibility: Evidence from Listed Companies in China
}

\author{
Xin Huang ${ }^{1}$, Xianling Jiang ${ }^{1}$, Wei Liu ${ }^{2, *}$ and Qian Chen ${ }^{1}$ \\ 1 School of International Trade and Economics, University of International Business and Economics, \\ Beijing 100029, China; 201700140015@uibe.edu.cn (X.H.); jiangxianling@uibe.edu.cn (X.J.); \\ 01700142002@uibe.edu.cn (Q.C.) \\ 2 Department of Finance, Business College of Beijing Union University, Beijing 100025, China \\ * Correspondence: wei.liu@buu.edu.cn
}

check for updates

Citation: Huang, X.; Jiang, X.; Liu, W.; Chen, Q. Business GroupAffiliation and Corporate Social Responsibility: Evidence from Listed Companies in China. Sustainability 2021, 13, 2110. https://doi.org/ $10.3390 /$ su13042110

Academic Editor: Ioannis Nikolaou

Received: 20 January 2021

Accepted: 12 February 2021

Published: 16 February 2021

Publisher's Note: MDPI stays neutral with regard to jurisdictional claims in published maps and institutional affiliations.

Copyright: (c) 2021 by the authors. Licensee MDPI, Basel, Switzerland. This article is an open access article distributed under the terms and conditions of the Creative Commons Attribution (CC BY) license (https:/ / creativecommons.org/licenses/by/ $4.0 /)$.

\begin{abstract}
Business groups have played a vital role in the development of emerging markets. However, we share very limited understanding in the role of business group that act on affiliated firms' CSR performance. Using manually sorted data on A-share listed companies and business groups in China from 2010-2017, we examine whether a company's business group-affiliation affects its corporate social responsibility (CSR) performance and the mediating mechanisms of this association. Our empirical models show that group companies bear a higher level of social responsibility compared to independent companies. This positive relationship between group-affiliation and social responsibility relies on resource allocation through internal capital markets, rent-seeking initiatives, and consideration of corporate reputation. Moreover, group affiliation benefits the firm's CSR performance in employee's responsibilities, consumers' responsibilities and environmental responsibilities, while significantly lower the shareholders' responsibilities. Our empirical valuation of group companies' CSR levels can serve as a benchmark for emerging market companies implementing social responsibility policies.
\end{abstract}

Keywords: business groups; CSR; internal capital market; rent-seeking; corporate reputation

\section{Introduction}

With the development of the social economy, emerging markets are increasingly paying attention to companies' Corporate Social Responsibility (CSR) performance. Policies and regulations in these countries actively require companies to fulfill social responsibilities, strengthen credit management, and disclose financial statements with transparency. For example, In China, the revised "Corporate Governance Guidelines for Listed Companies" issued by the China Securities Regulatory Commission (CSRC 2018), and the "Rules of Listing" on the Science and Technology Innovation Board of the Shanghai Stock Exchange (CSRC 2019) require listed companies to actively assume social responsibilities, safeguard public interests, and abide by their codes of conduct. Additionally, enterprises have themselves realized that social responsibility has become a new element of global competition, and sustainable development has become a key to solving global problems. Therefore, undertaking and fulfilling social responsibilities is an inevitable choice for enterprises to enhance their global soft power and international competitiveness.

The strategic management theory proposes that a company's corporate strategy is subject to its organizational form [1]. However, current research on social responsibility rarely take organizational form or groupwide factors into their considerations [2-5]. Existing studies have shown that firm's financial performance, financing cost, institutional environment, intellectual stimulation, consumer reactions and environmental sustainability are highly related to firm's performance on corporate social responsibility [6-8]. But almost all literatures simply lay emphasis on what matters for a "singular" firm to engage in CSR activities, ignoring the fact that firms may not operate as isolated units but have 
institutionalized relationships with each other and work coherently as an entity. A firm's business decisions are usually determined by its higher layer management, rather than independently the collective discussion within the firm.

Business groups have played a pivotal role in emerging market countries, especially in compensating the imperfections in the external capital market and institutional environment $[9,10]$. The internal capital market offers companies several advantages in economies of scope, economies of scale, resource allocation, and risk-sharing, which helps them enhance their market value [11]. Compared to an individual company, a business group has an additional management and control system at the group level [12]. However, the asymmetric information between the group headquarters and the group members may lead to unnecessary transactions and cross-subsidization among members, which can cause inefficient internal resource allocations, excessive investments, and decline in corporate value $[13,14]$.

Past studies on business groups seems to fall into the trouble in the argument of whether business groups are "paragons" or "parasites" [15-18], hence the relation of business group affiliation and firm performance and the role of the internal capital market are investigated among different countries in numerous literatures from different years, which still remains unsettled.

Presently, the topic of group affiliated firms and its CSR performance is highly relevant for emerging markets, which need more focus. During the last 50 years, many emerging markets have experienced major changes in economic reforms, which involves privatization and trade liberalization. An increasingly competitive business environment and sound institutional framework proposes higher demand and challenge to the role of business groups on undertaking responsibilities. Thus, it is interesting to study how business groups are responding to the fast change economies in fulfilling CSR.

Our research may contribute to explaining the role of business groups in the pursuit of sustainable development goals (SDGs) as well. The content and applicability of SDGs has been subject to heated discussion in recent years [19]. Ref. [20] pointed out that the private sector has a unique role in accelerating the progress of SDGs, due to their "financing sectorspecific expertise and knowledge, managerial and enforcement capacity, and a higher willingness to take risks" (p. 16). Given its market power and scope of activity, business group is one of the most essential agents in the achievement of SDGs. Investigating how CSR strategies are implemented within business groups help $\mathrm{u}$ better understand the role of organizations in tackling sustainable development.

In this regard, we try to bridge this gap by addressing three specific questions:

1. What is the role of affiliation of business groups in affecting member companies in fulfilling CSR?

2. What mechanisms work for the group companies' CSR performance?

3. What is the difference in detailed aspects of CSR between group companies and independent companies?

Based on existing studies, the implementation of CSR as a long-term strategy can be completely different in independent companies and group companies. First, in terms of focus areas, independent companies focus on fulfilling economic and a part of legal responsibilities, while business groups have a significant role in social responsibilities due to their advantageous position through industrial monopolies [21,22]. The public has relatively higher expectations from business groups, who not only expect them to be more charitable and morally responsible but also require them to have a higher level of social responsibility [23]. Second, the fulfillment of CSR makes companies rely on their group's support for material resources, social relations, and interpersonal connections [24]. Therefore, compared to independent companies, business groups' large size and diversified operations offer them greater access to material resources and increases their capacity to implement CSR. Third, gains in reputation and brand image through CSR are often collective; that is, reputation gain or loss is highly connected between business group and its members [25]. Different from independent companies, business groups need 
to put social responsibility at a higher strategic height to maintain and enhance their corporate image. Fourth, while the business groups' internal capital market brings various resource advantages to its members, it also increases the management's scope for tunneling behavior [26,27], which may reduce the members' agency and worsen the groups' overall CSR performance.

Centering the perspectives of business groups, this study attempts to explore the relationship between CSR and group-affiliation and its operational mechanisms. For this, we used the A-share listed companies in China from 2010-2017 to test whether there is a significant difference between the CSR performance of listed companies attached to business groups and independent listed companies.

This paper is organized as follows. Section 2 provides the literature review and research hypothesis. Section 3 develops research methods and definitions of variables. Section 4 presents the research results and tests for robustness, and finally, Section 5 provides a discussion and conclusion for the results.

\section{Literature Review and Research Hypothesis}

\subsection{Literature Review}

\subsubsection{Formation of Business Groups}

Many scholars have put forth a variety of theoretical explanations to study the formation and utility of business groups. Khanna and Rivkin (2001) defined a business group as "a set of firms, which though legally independent, are bound together by a constellation of formal and informal ties and are accustomed to taking coordinated actions." Business groups are generally considered beneficial to deal with external market imperfections and are especially advantageous in emerging economies where companies often face difficulties in obtaining bank loans due to insufficient investor protection and a shortage of financial intermediaries [28]. Therefore, companies have the incentive to build corporate groups to form an effective internal capital market to concentrate, develop, and store key resources not available in the external market [29]. Some domestic studies in China have also found that the establishment of business groups effectively allocates resources and has a positive impact on corporate R\&D activities [30,31].

However, subsequent studies have observed that the internal capital markets formed by business groups can be inefficient. According to the agency theory, self-interest maximizing induces agents in an agency relationship to invest their resources into low profit-high risk projects (including those with negative net present values). This enables them to use their control rights to conduct tunneling behavior [32] and encourages large shareholders to encroach on the interests of small and medium shareholders [33]. In addition, the pyramid structure widely adopted in business groups has increased the degree of separation between management control and cash flow rights which have aggravated the agency problem between controlling shareholders and small and medium shareholders as well [34,35]. These asymmetric information problems make controlling shareholders more likely to hollow out companies [36,37], affect the dividend policy of the holding company, reduce the distribution of cash dividends and exacerbate corruption and salary manipulation by senior executives [38]. These actions further increase financial costs, intensify financial constraints, and reduce the market value of the holding companies [39].

Besides, political economists also suggest that political resources are one of the key reasons that lead to the rise and development of business groups [40]. Ref [41] pointed out that the rapid growth of business groups is the response to government policies. Especially in emerging economies, government intervention is shown in many aspects of economic development and policy making. In order to protect weak industries and underdeveloped capital market, emerging markets usually implement protectionist policies to restrict the opening and access threshold. Thus, political connections are essential in a highly regulated environment. By engaging in rent-seeking activities, business group could acquire the government support and strategic resources, including funds, land, business certificate and tax preference [42]. 


\subsubsection{Business Organizations' Role in Pursuing CSR and Sustainable Development Goals}

The SDGs are an interconnected set of measurable goals designed to address interrelated challenges and achieve global sustainable development [43]. They are addressed to all actors in society: government, civil society, nonprofit organizations and the private sector. However, the private sector, especially the large multinational firms, is considered a key factor in the achievement of SDGs [44]. Ref [45] has argued that multinational corporations provide "world-wide reach, cutting-edge technologies, and massive capacity to reach large-scale solutions, which are all essential to success" in sustainable development.

Although the important role for business organizations to progress in SDGs, researches are remaining limited in understanding how business groups undertake their CSR strategies in emerging countries, where the sustainable development still lag far behind. Common wisdom holds that the motivation for investing CSR initiatives and integrating them into business strategy are grounded in a shared desire to ensure long-term success and survival of a firm. CSR strategies are taken into corporate decision making since they preserving the firm's license to operate, avoiding reputation damages, building loyalty and generating values in the long run. Unfortunately, very few studies highlight the implementation of CSR activities under a business group perspective [46-48].

Recently, [12,49] research about the relationship between business groups and CSR performance, offered great insights. However, they obtained diametrically opposite results and neither of them deepened their conclusions in testing the possible path empirically or digging out the difference on the various aspects of CSR. We try to provide new hypotheses and mechanisms based on rigorous empirical tests. Therefore, the subsequent parts of this paper aim to examine the influence of business groups on CSR in China.

\subsection{Hypothesis}

In this study, we assume that compared to independent companies, business group members have better social responsibility performances. We build our hypotheses on the following points. Firstly, undertaking CSR comes with greater financial pressures, especially in emerging economies, where companies require strong resource back-up, social relations, and other material conditions. Therefore, by building an internal capital market, group members can obtain adequate resource conditions [50], and reduce transaction costs. Chang and Hong find that group affiliated firms benefit from group membership through sharing intangible and financial resources, and various forms of internal business transactions [51]. Hopwood, Mellor, and O'Brien also point out that business group members could get access to financing internally, which lead to higher investment [52]. He et al. state that internal capital market is an important alternative financing channel that overcome constraints in raising external funds [53]. Additionally, Almeida and Wolfenzon highlighted the fact that the group's internal market provides members with a risk-sharing mechanism by reallocating all retained earnings and nondiverted payoff among the affiliated firms [54]. Thus, funds supporting within the group fully guarantee the decision making and investment on CSR activities.

Secondly, for business groups, the political environment is an important component of their business environment and a major institutional factor for their formation as an organizational model [55]. Particularly in emerging economies, socio-economic developmental policies often accompany more government interventions. Especially in strictly controlled external environments, building relationship a curial for business groups that rely on domestic and foreign resource networks as their main source of competitive advantage, the key is to build a network with foreign or domestic resources. Ref [56] suggest that personal relationships are the key for the entrepreneurship and evolution of business groups. An entrepreneurs' attributes and contextual factors are inseparable from the function of political connections. Therefore, obtaining government support through rent-seeking can help companies obtain strategic resources such as capital, land, operating permits, preferential policies, and market access. 
With respect to independent companies, business groups have greater incentives for rent-seeking due to their expanding scale and diversified operations. In competitive industries, active rent-seeking behavior enables groups to cross the high entry barriers and achieve higher sales revenues [57]. In addition, their large size and economic status also make it easier to negotiate with the government [40]. While rent seeking helps companies obtain scarce resources, it also comes with high costs. For instance, the need to undertake the government's policy goals for employment, taxation, and environmental protection. Therefore, business groups' rent-seeking needs force group members to perform higher levels of social responsibility [58,59].

Finally, group companies tend to undertake more CSR activities under the consideration and pressure of corporate reputation. As institutional theory proposes, corporate behaviors are restricted by regulation, standard and cultural cognition from external system environment, including mandatory pressures from laws and regulations, cultural and traditional pressures, expectations and public opinions [60]. With the expanding development of informatization, public opinions gradually become the main indicator on quality and corporate reputation of the company. A company's social image and reputation is a unique corporate resource. Its strong exclusivity and inimitability make it an intangible capital with strategic values. The continuous improvement of corporate reputation delivers multiple signals to external contractors, including corporate performance. This is an effective guarantee for reducing agency costs, obtaining more reputation rents, and long-term benefits [61,62].

A company's attitude towards social responsibility and its performance is one of the most important factors that affect its corporate reputation [63]. Unfortunately, public supervision does not put each firm on an equal footing. Unlike independent companies, business groups are attached great attention upon due to their influential market position.

Therefore, to maintain their existing corporate reputation and market position, business group members need to bear a higher CSR level.

Additionally, [64,65] also find that reputational gains or losses occurred to one firm may spillover to other organizations that are either proximate or structurally equivalent to the focal organization. That "bundling" relationship means that a reputation loss of a "black sheep" may involve other "innocent" fellow firms, which could lead to serious problems for the whole group. In this case, the spillover of reputation also requires that groups to place good social responsibility performance at a higher strategic position.

In summary, group companies tend to undertake a higher level of CSR through the allocation of resources in the internal capital market, and for rent-seeking and corporate reputation considerations. Therefore, we assume:

Hypothesis 1 (H1). Compared to independent companies, business group companies have better social responsibility performance.

Hypothesis 2 (H2). The role of business groups in promoting CSR is achieved through the mechanisms of resource allocation of internal capital market.

Hypothesis 3 (H3). The role of business groups in promoting CSR is achieved through their strong rent seeking motives.

Hypothesis $4 \mathbf{( H 4 ) . ~ T h e ~ r o l e ~ o f ~ b u s i n e s s ~ g r o u p s ~ i n ~ p r o m o t i n g ~ C S R ~ i s ~ a c h i e v e d ~ t h r o u g h ~ t h e ~}$ consideration of corporate reputation.

The advantages of group companies will also act on different dimensions of social responsibility. In the emerging market economy, due to imperfect capital markets, insufficient protection for investors, and institutional deficiency, independent companies are faced with stronger financing constraints and in turn need a sound business environment. The key of their strategic decisions is "how to survive", instead of "how to make it better". Therefore, independent companies pay more attention to the realization of economic 
responsibilities, and show less interest to non-economic goals such as ethics, law, and charity. For the group companies, the internal capital market of the group has greatly eased the financing problems, and the rent-seeking and corporate reputation mechanisms force group companies to perform full and diversified social responsibilities in non-economic fields. Therefore, we assume:

Hypothesis 5 (H5). Compared to independent companies, group affiliated firms have better performance in non-economic social responsibilities, but have lower performance in economic responsibilities.

\section{Research Design}

\subsection{Sample Selection and Data Sources}

For this study, we considered A-shares companies listed on either the Shenzhen or Shanghai Stock Exchanges from 2010 to 2017. For the data on business groups, we manually sort out the control chain relationship diagram provided by CSMAR (China Stock Market \& Accounting Research Database). The financial data of other listed companies also come from CSMAR and Wind databases. To arrive at our final sample selection, we exclude the samples of (1) financial companies; (2) PT and ST companies; (3) insolvent companies; and (4) the samples for which the final controller cannot be determined and the main variables are missing. To avoid the influence of extreme values, all of the continuous variables are winsorized at $1 \%$ and $99 \%$ levels.

\subsection{Selection of Key Variables}

\subsubsection{CSR}

There are several methods to measure CSR, including the content analysis method, the factor analysis method, and calculating the social contribution value per share. We mainly adopted Hexun's CSR ratings (Hexun Social Responsibility Report Ranking 2019) (named "CSR") and the social contribution value per share (named "CSR2") as our substitute variables [66,67]. The higher the score, the higher the corresponding rating level, and the better the CSR. Additionally, this paper divides Hexun's CSR score by 100, for a better comparison with the social contribution value per share.

\subsubsection{Business Group Affiliation}

The definition of business groups in this paper is consistent with that of [13,32]: if the parent company of a listed company owns other brokerage entities in addition to its subsidiaries, it is defined as a business group (Group $=1$ ). If the largest shareholders are SASAC (State-owned assets supervision and commission) companies; finance bureaus or other government agencies; or other companies or individuals that do not themselves engage in any business operations, but only in investment holding, they are considered to be an independent business (Group $=0$ ).

\subsection{Model Design}

To test hypothesis 1, drawing on the practice of existing research [68], we build the following model to test the impact of business groups on CSR:

$$
\operatorname{CSR}_{i, t}=\beta_{0}+\beta_{1} \text { Group }_{t}+\beta_{2} \text { Controls }_{t}+\sigma_{i}+\delta_{t}+\varepsilon
$$

Among them, $C S R_{i, t}$ represents a company's CSR score of the year; Group represents whether the company belongs to a business group; $\sigma_{i}$ and $\delta_{t}$ are used to control individual fixed effects and time fixed effects, respectively. The coefficient $\beta_{1}$ of the interaction term is the focus of this paper. Between independent companies and group companies, if group companies have higher CSR levels, we expect $\beta_{1}$ to be positive; conversely, if group companies have lower levels of CSR, then we expect $\beta_{1}$ to be negative. Based on existing researches $[24,53,68]$, we selected the following as control variables (Controls): the holding company's corporate size (Size); return on assets (ROA); capital structure (Lev); ownership 
concentration (SHRCR1); number of directors (Director); and the proportion of independent directors (Indep). Thereafter, we adopted lag processing for all the explanatory variables to reduce the impact of endogeneity. At the same time, to avoid the impact of the firmlevel clustering effect on the standard error, we performed a regression clustering at the firm level.

To verify $\mathrm{H} 2$ to $\mathrm{H} 4$, namely the effectiveness of the three mechanisms in promoting business groups' CSR, we used two different approaches which is designed as follows:

1. for recourse allocation of internal capital market

To test the mechanism of the internal capital market, we examined whether the CSR level of a sample of the business group is significantly related to the cash flows of other members of the same group [69]. The specific model is as follows:

$$
\operatorname{CSR}_{i, t}=\beta_{0}+\beta_{1} \text { OtherOCF }_{t}+\beta_{2} \text { OCF }_{t}+\beta_{3} \text { Controls }_{t}+\sigma_{i}+\delta_{t}+\varepsilon
$$

In model (2), "OtherOCF" represents the operating cash flows of other companies in the same group and "OCF" represents the company's operating cash flow. The other control variables are the same as in model (1). Model (2) focuses on analyzing whether the CSR level of listed companies depends on the operating cash flows of other companies within the group (OtherOCF). If the coefficient is significantly positive, it indicates that the group reasonably allocates group resources through the internal capital market and promotes the implementation of CSR.

2. for rent-seeking \& corporate reputation

We used the approaches outlined by $[70,71]$ to test our mediation effect of rent-seeking and corporate reputation. Although Sobel's procedure is commonly used and powerful, it works effectively unless ab is normally distributed, which is hardly tenable ("a" measures the effect between independent variable and mediation variable, " $b$ " measures the effect between dependent variable and mediation variable). Hence, we further verify our conclusion through the application of bootstrapped confidence intervals.

For rent-seeking mechanism, drawing lessons from the research of $\mathrm{Du}, \mathrm{Chen}$, and $\mathrm{Du}$ (2010) [72], the excess administrative expense (EAE) is used as a substitute variable to measure the rent-seeking behavior. The calculation method of EAE is as follows: First, the expected administrative expenses $(\overline{A E})$ of the company are estimated by constructing a model. The specific model is as follows:

$$
\begin{gathered}
A E_{i, t}=\beta_{0}+\beta_{1} \text { Sales }_{t}+\beta_{2} \text { Lev }_{t}+\beta_{3} \text { Growth }_{t}+\beta_{4} \text { Director }_{t}+\beta_{5} \text { Staff }_{t}+\beta_{6} \text { Auditor }_{t}+\beta_{7} \text { Age }_{t}+\beta_{8} \text { Prclevel }_{t} \\
+\beta_{9} H I_{t}+\beta_{10} \text { Margin }_{t}+\beta_{11} P P E_{t}+\sigma_{i}+\delta_{t}+\varepsilon
\end{gathered}
$$

Through regression, the fitted value of $A E$ is obtained; namely $\overline{A E}$. Then the difference between $A E$ and $\overline{A E}$ is calculated to get the excess management expense EAE. Among them, " $A E$ " represents the ratio of corporate administration expenses to the main operating income, while "Sales" represents the natural logarithm of corporate operating income; "Lev" the corporate leverage, and "Growth" the growth rate of total assets. "Director" and "Staff" respectively represent the size of the board of directors, and the number of employees, while "Auditor" represents whether the auditor is from the Big Four accounting firms. "Age" stands for the company's listing age, "Prclevel" the average salary of employees, and " $H I$ " the concentration of equity, which is equal to the Herfindahl index of the top five shareholders. Finally, "Margin" and "PPE" depict the company's gross profit margin and the proportion of fixed assets in total assets, respectively.

For corporate reputation mechanism, we use the variable "Fame" to represent corporate reputation [66]. That is, if a company enters the industry list from "Fortune Magazine" (Chinese version) in $\mathrm{T}+1$ year, Fame is defined as 1 , otherwise, it is 0 .

Hexun's CSR scoring system of listed companies facilitates our verification of the H5. According to different scoring indicators, Hexun's CSR scoring system of listed companies is divided into shareholders' responsibility, employees' responsibility, supplier and con- 
sumers' responsibility, environmental responsibility and social welfare. ("Shareholders' responsibility" mainly includes corporate profitability, solvency, the shareholders' ability to bring returns, information disclosure, and innovation capabilities; "Employees' responsibility" includes employee performance, employee safety, and concern for employees; "Supplier, customer and consumers' responsibility" includes product quality and after-sales service and integrity evaluation; "environmental responsibility" evaluates the corporate environmental governance capability; "Social welfare" measures the value of corporate contributions, including income tax and the amount of public welfare donations. Note: In order to avoid confusion, the original scoring system's "Social Responsibility" component was renamed "Social Welfare."). We consider shareholders' responsibility as a performance of corporate economic responsibilities, while other responsibilities as non-economic responsibilities, to further test the performance differences between group companies and independent companies in fulfilling CSR.

The specific definition and calculation methods of the variables in this study are shown in Table 1.

Table 1. Name and definition of main variables.

\begin{tabular}{|c|c|c|}
\hline Variable Symbol & Variable Name & Definition \\
\hline CSR & Corporate social responsibility & Hexun's CSR evaluation score \\
\hline CSR2 & Social contribution value per share & $\begin{array}{l}\text { Social contribution value per share }=(\text { net profit }+ \text { income tax } \\
\text { expense }+ \text { business tax and surcharges }+ \text { Cash paid to and for } \\
\text { employees }+ \text { Payroll payable in the current period }- \text { Payroll } \\
\text { payable in the previous period }+ \text { financial cost }+ \text { donation }- \\
\text { sewage charge and cleaning up cost }) / \text { average of the total } \\
\text { number of shares at the beginning and end of the period }\end{array}$ \\
\hline Group & Business group & $\begin{array}{l}\text { If the parent company of a listed company owns other } \\
\text { brokerage entities in addition to subsidiaries, then Group }=1 \text {; } \\
\text { if the largest shareholder is the SASAC, state-owned asset } \\
\text { management companies, finance bureaus or other } \\
\text { government agencies, or other companies or individuals that } \\
\text { do not engage in any business operations, then Group }=0 \text {. }\end{array}$ \\
\hline Size & Corporate size & Natural logarithm of a company's total assets \\
\hline ROA & Return on assets & Ratio of net profit to total assets \\
\hline Lev & Financial leverage & Ratio of total liabilities to total assets \\
\hline Shrcr1 & Ownership concentration & Proportion of the largest shareholder \\
\hline Director & Number of directors & Total number of corporate directors \\
\hline Indep & Independent director & $\begin{array}{l}\text { Ratio of the number of independent directors to the number } \\
\text { of all directors on the board }\end{array}$ \\
\hline Duality & Duality & $\begin{array}{l}\text { If the chairman of the board and the general manager are the } \\
\text { same person, it is 1; otherwise, it is } 0\end{array}$ \\
\hline MB & Book-to-market & Ratio of total asset market value to book value \\
\hline PPE & Tangibility of assets & Ratio of net fixed assets to total assets \\
\hline
\end{tabular}

\subsection{Descriptive Statistics}

Table 2 shows the descriptive statistics of the main variables. It shows that the average level of CSR in the sample is 0.253 and the median is 0.221 , which is far from the maximum value, indicating that most companies have room for improvement in terms of their CSR performance. The mean value of the dummy variable is 0.653 , indicating that $65.3 \%$ of the sample businesses belong to business groups. In terms of control variables, the average leverage ratio is 0.395 , indicating that the leverage ratio of the listed companies is not too high. The average shareholding ratio of the largest shareholder is $34.897 \%$, showing the relatively concentrated equity of listed companies in China. The average value of the 
proportion of independent directors is 0.374 , which means that the sample companies as a whole meet the basic requirements of China's corporate governance code. The results of other control variables are consistent with the existing literature.

Table 2. Descriptive statistics of main variables.

\begin{tabular}{ccccccccc}
\hline Variables & Sample Size & Mean & SD & p5 & p25 & p50 & p75 & p95 \\
\hline CSR & 21,273 & 0.253 & 0.169 & 0.017 & 0.164 & 0.221 & 0.283 & 0.656 \\
CSR2 & 21,273 & 0.121 & 0.097 & 0.002 & 0.061 & 0.106 & 0.165 & 0.305 \\
Group & 21,273 & 0.653 & 0.476 & 0.000 & 0.000 & 1.000 & 1.000 & 1.000 \\
Size & 21,273 & 21.950 & 1.247 & 20.221 & 21.067 & 21.796 & 22.653 & 24.289 \\
ROA & 21,273 & 0.037 & 0.058 & -0.042 & 0.011 & 0.034 & 0.064 & 0.129 \\
Lev & 21,273 & 0.395 & 0.218 & 0.069 & 0.218 & 0.382 & 0.554 & 0.775 \\
Shrcr1 & 21,273 & 34.897 & 15.003 & 13.561 & 23.120 & 32.940 & 45.034 & 62.519 \\
Director & 21,273 & 8.670 & 1.718 & 6.000 & 7.000 & 9.000 & 9.000 & 11.000 \\
Indep & 21,273 & 0.374 & 0.053 & 0.333 & 0.333 & 0.333 & 0.429 & 0.500 \\
Duality & 21,273 & 0.258 & 0.438 & 0.000 & 0.000 & 0.000 & 1.000 & 1.000 \\
MB & 21,273 & 0.933 & 0.934 & 0.162 & 0.361 & 0.621 & 1.118 & 2.885 \\
PPE & 21,273 & 0.171 & 0.160 & 0.001 & 0.043 & 0.127 & 0.254 & 0.509 \\
\hline
\end{tabular}

Table 3 lists the differences in the related variables between group companies and independent companies. The table shows that the level of social responsibility undertaken by group companies is significantly higher than that of independent companies, which is consistent with H1. Additionally, compared to independent companies, group companies are greater in terms of size, ROA, ownership concentration, and the number of board members. In independent companies, the duality is more commonly seen, and more emphasis is placed on the appointment of independent directors.

Table 3. Tests on the differences of variables between group companies and independent companies.

\begin{tabular}{|c|c|c|c|c|c|}
\hline \multirow{2}{*}{ Variables } & \multicolumn{2}{|c|}{ Group Companies $(\mathrm{N}=13,893)$} & \multicolumn{2}{|c|}{ Independent Companies $(\mathrm{N}=7380)$} & \multirow{2}{*}{ Difference Test } \\
\hline & Mean & SD & Mean & SD & \\
\hline CSR & 0.271 & 0.184 & 0.220 & 0.130 & $0.050^{* * *}$ \\
\hline Size & 22.061 & 1.282 & 21.740 & 1.148 & $0.320^{* * *}$ \\
\hline $\mathrm{ROA}$ & 0.037 & 0.037 & 0.037 & 0.063 & 0.001 \\
\hline Lev & 0.419 & 0.222 & 0.350 & 0.203 & $0.069^{* * *}$ \\
\hline Shrcr1 & 36.772 & 15.245 & 31.366 & 13.866 & $5.405^{* * *}$ \\
\hline Director & 8.844 & 1.743 & 8.342 & 1.620 & $0.502^{* * *}$ \\
\hline Indep & 0.371 & 0.052 & 0.379 & 0.055 & $-0.008^{* * *}$ \\
\hline Duality & 0.208 & 0.406 & 0.354 & 0.478 & $-0.146^{* * *}$ \\
\hline $\mathrm{MB}$ & 0.978 & 0.956 & 0.847 & 0.885 & $0.132^{* * *}$ \\
\hline PPE & 0.181 & 0.169 & 0.153 & 0.139 & $0.028^{* * *}$ \\
\hline
\end{tabular}

Note: ${ }^{* * *}$ represent significant at $1 \%$ levels.

\section{Empirical Results and Robustness Checks}

\subsection{Business Group Affiliation and CSR}

Table 4 shows the results of OLS regression analysis on the relation between business group affiliation and CSR. Column 1 and Column 2 reports the results of two different CSR measures respectively. Our findings suggest that group members assume better CSR performance, which is significant at the level of $1 \%$ and $5 \%$ respectively $(\beta=0.010$, $\rho<0.01 ; \beta=0.004, \rho<0.05$ ), supporting our hypothesis H1. Specifically, group affiliation benefits firms an average $4 \%(0.01 / 0.253)$ higher in CSR rating scores than independent companies (column 1). Moreover, our results also show CSR is positively related to financial performance, which are totally aligned with [24]. 
Table 4. Business group affiliation and csr.

\begin{tabular}{|c|c|c|}
\hline & (1) & (2) \\
\hline & CSR & CSR2 \\
\hline Group & $\begin{array}{c}0.010 * * * \\
(2.70)\end{array}$ & $\begin{array}{c}0.004^{* *} \\
(2.02)\end{array}$ \\
\hline ROA & $\begin{array}{c}0.649 * * * \\
(30.09)\end{array}$ & $\begin{array}{c}0.992 * * * \\
(69.41)\end{array}$ \\
\hline Lev & $\begin{array}{c}-0.059 * * * \\
(-7.22)\end{array}$ & $\begin{array}{l}0.002 \\
(0.45)\end{array}$ \\
\hline Size & $\begin{array}{c}0.042 * * * \\
(17.71)\end{array}$ & $\begin{array}{c}-0.011^{* * *} \\
(-10.74)\end{array}$ \\
\hline Shrcr1 & $\begin{array}{l}0.000 \\
(0.95)\end{array}$ & $\begin{array}{c}0.000 * * * \\
(7.34)\end{array}$ \\
\hline Director & $\begin{array}{l}0.227 \\
(1.40)\end{array}$ & $\begin{array}{c}0.003^{* * *} \\
(5.52)\end{array}$ \\
\hline Duality & $\begin{array}{c}-0.693^{* *} \\
(-2.02)\end{array}$ & $\begin{array}{c}-0.004 \text { ** } \\
(-2.44)\end{array}$ \\
\hline MB & $\begin{array}{c}-0.950 * * * \\
(-3.36)\end{array}$ & $\begin{array}{c}-0.003^{* *} \\
(-2.34)\end{array}$ \\
\hline PPE & $\begin{array}{c}-0.052 * * * \\
(-5.18)\end{array}$ & $\begin{array}{c}-0.020^{* * *} \\
(-4.42)\end{array}$ \\
\hline constant & $\begin{array}{c}-0.785^{* * *} \\
(-13.77)\end{array}$ & $\begin{array}{c}0.281 * * * \\
(11.40)\end{array}$ \\
\hline Cluster & Yes & Yes \\
\hline $\mathrm{FE}$ & Yes & Yes \\
\hline $\mathrm{N}$ & 21,273 & 21,273 \\
\hline Adj_R2 & 0.218 & 0.381 \\
\hline
\end{tabular}

Note: ${ }^{* * *}$ and ${ }^{* *}$ represent significant at $1 \%$ and $5 \%$ levels, respectively; The $\mathrm{t}$ value is in brackets; the standard error is cluster-adjusted at the company level.

\subsection{Mechanism Test Results}

\subsubsection{Resource Allocation of Internal Capital Market}

Table 5 shows the test results of the internal capital market's resource allocation mechanism. We find that after controlling the cash flow that generate inside the firm (OCF), the amount of operating cash flow from other fellow companies in the group (OtherOCF) is significantly related to the firm's CSR performance $(\beta=0.010, \rho<0.01)$. It indicates business groups could allocate available funds efficiently within the group to where meets financial constraints, which supports our hypothesis $\mathrm{H} 2$ that internal capital market works for the improvement of CSR.

Table 5. Analysis of influential mechanism (internal capital market).

\begin{tabular}{ccc}
\hline & $\mathbf{( 1 )}$ & $\mathbf{( 2 )}$ \\
\hline & CSR & CSR \\
\hline OtherOCF & $0.037^{* * *}$ & $0.030^{* * *}$ \\
& $(4.00)$ & $(3.53)$ \\
OCF & $3.453^{* * *}$ & $2.835^{* * *}$ \\
& $(4.63)$ & $(3.32)$ \\
ROA & & $59.462^{* * *}$ \\
& & $(19.65)$ \\
Lev & & $-7.766^{* * *}$ \\
Size & & $(-7.63)$ \\
& & $4.427^{* * *}$ \\
\end{tabular}


Table 5. Cont.

\begin{tabular}{ccc}
\hline & $\mathbf{( 1 )}$ & $\mathbf{( 2 )}$ \\
\hline Shrcr1 & CSR & CSR \\
\hline Director & & 0.009 \\
& & $(0.37)$ \\
Duality & & $0.363^{*}$ \\
& & $(1.72)$ \\
MB & & -0.537 \\
& & $(-1.19)$ \\
PPE & & -0.570 \\
& & $(-1.60)$ \\
constant & $18.920 * * *$ & $-4.874^{* * *}$ \\
& $(38.80)$ & $(-3.90)$ \\
Cluster & Yes & $-85.482^{* * *}$ \\
FE & Yes & $(-11.97)$ \\
N & 13,893 & Yes \\
Adj_R2 & 0.128 & Yes \\
\hline repres & 0.200 \\
\hline
\end{tabular}

Note: ${ }^{* * *}$ and ${ }^{*}$ represent significant at $1 \%$ and $10 \%$ levels, respectively; The $t$ value is in brackets; the standard error is cluster-adjusted at the company level.

\subsubsection{Rent-Seeking \& Corporate Reputation Mechanism}

In Table 6, we provide Sobel's $Z$ value and estimates of the direct and indirect effects, along with the symmetric and $95 \%$ bias-corrected bootstrapped confidence intervals. For rent-seeking mechanism, the Sobel's $Z$ value is 1.691, which is significant at $10 \%$ level, and zero is not involved in the bootstrapped $95 \%$ confidence interval at the same time. It supports that group companies tend to engage in rent-seeking behaviors in expense of a high level of CSR. Table 6 also shows that Sobel's $Z$ value for corporate reputation is 3.344 and reaches the significant level of $1 \%$, and zero is out of the bootstrapped confidence intervals as well, which proves the corporate reputation path. Consequently, "rent-seeking" and "corporate reputation" have mediating effects on the relationship between business group affiliation and CSR, which contributes to $6 \%$ of the gain in CSR performance respectively. These results are in consistent with our hypotheses $\mathrm{H} 3$ and $\mathrm{H} 4$.

Table 6. Mediation effects test.

\begin{tabular}{|c|c|c|c|c|c|c|c|c|}
\hline \multirow{3}{*}{ Mediation Variable } & \multicolumn{2}{|r|}{ Sobel Test } & \multicolumn{6}{|c|}{ Bootstrap CI (95\%) } \\
\hline & \multirow[t]{2}{*}{$\mathbf{Z}$} & \multirow[t]{2}{*}{ Mediated Proportion } & \multicolumn{3}{|c|}{ Indirect Effect } & \multicolumn{3}{|c|}{ Direct Effect } \\
\hline & & & $\mathrm{CI}_{\text {low }}$ & $\mathrm{CI}_{\text {high }}$ & Effect & $\mathrm{CI}_{\text {low }}$ & $\mathrm{CI}_{\text {high }}$ & Effect \\
\hline EAE & $1.691 *$ & 0.0629 & 0.0003 & 0.0024 & 0.0016 & 0.0210 & 0.0566 & 0.0234 \\
\hline Fame & $\underset{* * *}{3.344}$ & 0.0564 & 0.0002 & 0.0009 & 0.0005 & 0.0041 & 0.0139 & 0.0091 \\
\hline
\end{tabular}

Note: *** and * represent significant at $1 \%$ and $10 \%$ levels, respectively.

\subsection{Detailed Variation of CSR}

We showed that group-affiliation do benefit a company in fulfilling CSR from previous sections. In this part, we try to figure out this promotion works on what aspects of responsibilities. Table 7 shows the results. Group-affiliation improves members' CSR performance on employees' responsibility $(\beta=0.004, \rho<0.01)$, consumers' responsibility $(\beta=0.005, \rho<0.01)$ and environmental responsibility $(\beta=0.005, \rho<0.01)$, but deteriorates the shareholders' responsibility. These differences indicate that group-companies attach great importance on non-economic responsibilities instead of economic responsibilities, which is in support of our hypothesis H3. 
Table 7. Five Dimensions of business groups and CSR.

\begin{tabular}{|c|c|c|c|c|c|}
\hline & (1) & (2) & (3) & (4) & (5) \\
\hline & $\begin{array}{l}\text { Shareholders' } \\
\text { Responsibility }\end{array}$ & $\begin{array}{c}\text { Employees' } \\
\text { Responsibility }\end{array}$ & $\begin{array}{c}\text { Consumers' } \\
\text { Responsibility }\end{array}$ & $\begin{array}{l}\text { Environmental } \\
\text { Responsibility }\end{array}$ & $\begin{array}{c}\text { Social } \\
\text { Welfare }\end{array}$ \\
\hline Group & $\begin{array}{c}-0.004^{* * *} \\
(-2.70)\end{array}$ & $\begin{array}{c}0.004^{* * *} \\
(4.72)\end{array}$ & $\begin{array}{c}0.005^{* * *} \\
(4.08)\end{array}$ & $\begin{array}{c}0.005^{* * *} \\
(3.70)\end{array}$ & $\begin{array}{l}0.001 \\
(0.73)\end{array}$ \\
\hline ROA & $\begin{array}{c}0.551 \text { *** } \\
(52.14)\end{array}$ & $\begin{array}{l}-0.001 \\
(-0.17)\end{array}$ & $\begin{array}{l}-0.004 \\
(-0.70)\end{array}$ & $\begin{array}{l}-0.005 \\
(-0.77)\end{array}$ & $\begin{array}{c}0.122^{* * *} \\
(17.76)\end{array}$ \\
\hline Lev & $\begin{array}{l}-0.004^{* * *} \\
(-12.88)\end{array}$ & $\begin{array}{l}-0.002 \\
(-1.29)\end{array}$ & $\begin{array}{l}-0.006^{* *} \\
(-2.40)\end{array}$ & $\begin{array}{l}-0.006^{* *} \\
(-2.13)\end{array}$ & $\begin{array}{c}-0.008^{* * * *} \\
(-2.93)\end{array}$ \\
\hline Size & $\begin{array}{c}0.017^{* * *} \\
(21.34)\end{array}$ & $\begin{array}{c}0.006^{* * *} \\
(11.01)\end{array}$ & $\begin{array}{c}0.007^{* * *} \\
(8.74)\end{array}$ & $\begin{array}{c}0.008^{* * *} \\
(9.68)\end{array}$ & $\begin{array}{c}0.005^{* * *} \\
(6.93)\end{array}$ \\
\hline Shrcr1 & $\begin{array}{c}0.000^{* * *} \\
(7.48)\end{array}$ & $\begin{array}{c}-0.000^{* *} \\
(-2.44)\end{array}$ & $\begin{array}{l}-0.000 \\
(-1.62)\end{array}$ & $\begin{array}{c}-0.000 * \\
(-1.73)\end{array}$ & $\begin{array}{l}0.000 \\
(1.09)\end{array}$ \\
\hline Director & $\begin{array}{l}0.000 \\
(0.82)\end{array}$ & $\begin{array}{l}0.000 \\
(1.41)\end{array}$ & $\begin{array}{l}0.000 \\
(0.68)\end{array}$ & $\begin{array}{l}0.000 \\
(0.98)\end{array}$ & $\begin{array}{l}0.000 \\
(1.54)\end{array}$ \\
\hline Duality & $\begin{array}{l}0.000 \\
(0.19)\end{array}$ & $\begin{array}{c}-0.002 * * \\
(-2.22)\end{array}$ & $\begin{array}{l}-0.002 \\
(-1.41)\end{array}$ & $\begin{array}{l}-0.002 * \\
(-1.67)\end{array}$ & $\begin{array}{c}-0.002 \text { ** } \\
(-2.11)\end{array}$ \\
\hline MB & $\begin{array}{c}-0.008^{* * *} \\
(-9.67)\end{array}$ & $\begin{array}{l}-0.001 \\
(-1.51)\end{array}$ & $\begin{array}{l}-0.001 \\
(-1.20)\end{array}$ & $\begin{array}{l}-0.001 \\
(-1.24)\end{array}$ & $\begin{array}{c}0.002^{* *} \\
(2.30)\end{array}$ \\
\hline PPE & $\begin{array}{c}-0.023 * * * \\
(-7.22)\end{array}$ & $\begin{array}{c}-0.008^{* * *} \\
(-4.08)\end{array}$ & $\begin{array}{c}-0.007^{* *} \\
(-2.05)\end{array}$ & $\begin{array}{c}-0.008^{* *} \\
(-2.20)\end{array}$ & $\begin{array}{c}-0.007^{* * * *} \\
(-2.76)\end{array}$ \\
\hline _cons & $\begin{array}{l}-0.244^{* * *} \\
(-13.19)\end{array}$ & $\begin{array}{c}-0.119 * * * \\
(-9.47)\end{array}$ & $\begin{array}{c}-0.154^{* * *} \\
(-8.48)\end{array}$ & $\begin{array}{c}-0.187^{* * *} \\
(-9.46)\end{array}$ & $\begin{array}{c}-0.093^{* * * *} \\
(-5.28)\end{array}$ \\
\hline Cluster & Yes & Yes & Yes & Yes & Yes \\
\hline $\mathrm{FE}$ & Yes & Yes & Yes & Yes & Yes \\
\hline $\mathrm{N}$ & 21,273 & 21,273 & 21,273 & 21,273 & 21,273 \\
\hline Adj_R2 & 0.461 & 0.123 & 0.136 & 0.131 & 0.051 \\
\hline
\end{tabular}

Note: ***** and * represent significant at $1 \%, 5 \%$ and $10 \%$ levels, respectively; The $t$ value is in brackets; the standard error is cluster-adjusted at the company level.

We've also noticed that no significant difference appeared between group companies and independent companies. Since "social welfare" measures the sum of income tax and public welfare donations, this is possible that group companies are capable of engaging in donation supported by the whole group, while independent companies pay more income taxes due to their eager in pursuit of economic responsibilities.

\subsection{Summary of Estimation Results}

So far, our results have shown that group affiliation elevates firms' social responsibility, which works with the assistance of internal capital market and considerations of rentseeking privileges and corporate reputation. Group affiliated firms are advantage in responsible for employees, consumers and environment. We summarize our hypotheses and findings in Table 8.

Table 8. Hypotheses and findings.

\begin{tabular}{cc}
\hline Hypotheses & Findings \\
\hline H1: Group affiliation-CSR & positive \\
positive \\
positive \\
positive \\
H4: Mediating effect of internal capital market & $\begin{array}{c}\text { podiating effect of corporate reputation } \\
\text { H5: Group affiliated firms are better engaged in }\end{array}$ \\
non-economic responsibilities instead of economic & $\begin{array}{c}\text { Higher performance in employees', consumers' and environmental } \\
\text { responsibilities, lower performance in shareholders' responsibilities, } \\
\text { no significant difference in social welfare }\end{array}$ \\
\hline
\end{tabular}




\subsection{Robustness Checks}

Given the endogenous problems that may appear in this research, we conduct robust checks by replacing the measure of business groups, adding group-level control variables, considering equity nature problems, propensity score matching and hackman procedures to further verify robustness of our conclusions.

\subsubsection{Assessing the Method of Measuring Business Groups}

To ensure objectivity in measuring business groups, we used the definition of business groups as applied by [53] and [69]. If the ultimate controller of a listed company controls more than two listed companies in the same year, it is defined as a group listed company (Group1 =1), otherwise, it is considered as an independent company (Group1 =0). This definition was applied in Model (1) for regression analysis. The results of the regression analysis are shown in Table 9, which are still consistent with the main regression $(\beta=0.017$, $\rho<0.01 ; \beta=0.006, \rho<0.01)$, indicating that the results of this paper have a certain degree of objectivity.

Table 9. Robustness checks (replace substitute variables).

\begin{tabular}{|c|c|c|}
\hline & (1) & (2) \\
\hline & CSR & CSR2 \\
\hline Group1 & $\begin{array}{c}0.017^{* * *} \\
(3.04)\end{array}$ & $\begin{array}{c}0.006^{* * *} \\
(3.40)\end{array}$ \\
\hline ROA & $\begin{array}{c}0.804^{* * *} \\
(39.37)\end{array}$ & $\begin{array}{c}0.994^{* * *} \\
(69.27)\end{array}$ \\
\hline Lev & $\begin{array}{c}-0.006^{* * *} \\
(-8.75)\end{array}$ & $\begin{array}{l}0.004 \\
(0.77)\end{array}$ \\
\hline Size & $\begin{array}{c}0.045^{* * *} \\
(28.47)\end{array}$ & $\begin{array}{c}-0.012^{* * *} \\
(-11.00)\end{array}$ \\
\hline Shrcr1 & $\begin{array}{c}0.000 * * * \\
(2.68)\end{array}$ & $\begin{array}{c}0.000 * * * \\
(7.41)\end{array}$ \\
\hline Director & $\begin{array}{c}0.003^{* * *} \\
(2.77)\end{array}$ & $\begin{array}{c}0.003^{* * *} \\
(5.02)\end{array}$ \\
\hline Duality & $\begin{array}{l}-0.002 \\
(-0.73)\end{array}$ & $\begin{array}{c}-0.003 \text { ** } \\
(-2.05)\end{array}$ \\
\hline MB & $\begin{array}{c}-0.019^{* * *} \\
(-4.69)\end{array}$ & $\begin{array}{c}-0.003^{* * *} \\
(-2.66)\end{array}$ \\
\hline PPE & $\begin{array}{c}-0.048^{* * *} \\
(-5.56)\end{array}$ & $\begin{array}{c}-0.021^{* * *} \\
(-4.58)\end{array}$ \\
\hline constant & $\begin{array}{c}-0.868 \text { *** } \\
(-23.77)\end{array}$ & $\begin{array}{c}0.290 * * * \\
(11.73)\end{array}$ \\
\hline Cluster & Yes & Yes \\
\hline $\mathrm{FE}$ & Yes & Yes \\
\hline $\mathrm{N}$ & 20,968 & 20,968 \\
\hline Adj_R2 & 0.215 & 0.379 \\
\hline
\end{tabular}

Note: ${ }^{* * *}$ and ${ }^{* *}$ represent significant at $1 \%$ and $5 \%$ levels, respectively; The $t$ value is in brackets; the standard error is cluster-adjusted at the company level.

\subsubsection{Increase Group-Level Control Variables}

In addition to its material conditions, the strategic decision of a group company could be largely influenced at the group level. Therefore, based on existing studies, this paper further controlls for the group headquarters' average control over its members and the total return on assets (ROA) of the fellow members, and the results do not change significantly. See Table 10. 
Table 10. Robustness checks (add control variables).

\begin{tabular}{|c|c|c|}
\hline & (1) & (2) \\
\hline & CSR & CSR2 \\
\hline Group & $\begin{array}{c}0.009 * * * \\
(2.76)\end{array}$ & $\begin{array}{c}0.004^{* *} \\
(2.10)\end{array}$ \\
\hline ROA & $\begin{array}{c}0.802 * * * \\
(38.41)\end{array}$ & $\begin{array}{c}0.986^{* * *} \\
(68.23)\end{array}$ \\
\hline Lev & $\begin{array}{c}-0.062 * * * \\
(-8.95)\end{array}$ & $\begin{array}{l}0.002 \\
(0.47)\end{array}$ \\
\hline Size & $\begin{array}{c}0.045^{* * *} \\
(28.79)\end{array}$ & $\begin{array}{c}-0.011^{* * *} \\
(-10.66)\end{array}$ \\
\hline Shrcr1 & $\begin{array}{c}0.000 * * \\
(2.49)\end{array}$ & $\begin{array}{c}0.000^{* * *} \\
(7.14)\end{array}$ \\
\hline Director & $\begin{array}{c}0.003^{* * *} \\
(2.82)\end{array}$ & $\begin{array}{c}0.003 * * * \\
(5.53)\end{array}$ \\
\hline duality & $\begin{array}{l}-0.003 \\
(-1.22)\end{array}$ & $\begin{array}{c}-0.004 \text { ** } \\
(-2.49)\end{array}$ \\
\hline MB & $\begin{array}{c}-0.010 * * * \\
(-4.49)\end{array}$ & $\begin{array}{c}-0.003 \text { ** } \\
(-2.34)\end{array}$ \\
\hline PPE & $\begin{array}{c}-0.048^{* * *} \\
(-5.54)\end{array}$ & $\begin{array}{c}-0.019 * * * \\
(-4.36)\end{array}$ \\
\hline control & $\begin{array}{l}0.000 \\
(0.02)\end{array}$ & $\begin{array}{l}0.000 \\
(0.18)\end{array}$ \\
\hline GroupROA & $\begin{array}{l}-0.047 \\
(-0.61)\end{array}$ & $\begin{array}{l}0.078 * \\
(1.84)\end{array}$ \\
\hline constant & $\begin{array}{c}-0.874^{* * *} \\
(-23.81)\end{array}$ & $\begin{array}{c}0.277^{* * *} \\
(11.13)\end{array}$ \\
\hline Cluster & Yes & Yes \\
\hline FE & Yes & Yes \\
\hline $\mathrm{N}$ & 21,246 & 21,246 \\
\hline Adj_R2 & 0.215 & 0.382 \\
\hline
\end{tabular}

Note: ${ }^{* * *},{ }^{* *}$ and ${ }^{*}$ represent significant at $1 \%, 5 \%$ and $10 \%$ levels, respectively; The $t$ value is in brackets; the standard error is cluster-adjusted at the company level.

\subsubsection{Eliminating Endogenous Problems Caused by the Nature of Property Rights}

Due to the special conditions for the establishment of state-owned enterprise (SOE) groups and the accompanying mission of undertaking social responsibility from their inception, SOE groups may have more serious endogeneity problems in the empirical results. We implement two ways to mitigate these problems: (1) Eliminating SOEs before performing the regression. (2) Replacing the explained variable with the incremental CSR scores (CSRL and CSR2L), which is used to eliminate the stable quantity of CSR. The incremental CSR scores are used as the substitute variable for the change in CSR. The results are shown in column 1,2 and column 3,4 of Table 11, respectively. While the results do not change significantly, it validates our main findings. 
Table 11. Robustness checks (samples of SOEs excluded and incremental CSR scores).

\begin{tabular}{|c|c|c|c|c|}
\hline & (1) & (2) & (3) & (4) \\
\hline & CSR & CSR & CSRL & CSR2L \\
\hline Group & $\begin{array}{c}0.004^{* * *} \\
(7.88)\end{array}$ & $\begin{array}{c}0.004^{* *} \\
(2.21)\end{array}$ & $\begin{array}{c}0.003^{* *} \\
(1.99)\end{array}$ & $\begin{array}{c}0.005^{* * *} \\
(3.59)\end{array}$ \\
\hline ROA & $\begin{array}{c}0.869^{* * *} \\
(34.50)\end{array}$ & $\begin{array}{c}1.004^{* * *} \\
(58.10)\end{array}$ & $\begin{array}{c}0.426^{* * *} \\
(18.98)\end{array}$ & $\begin{array}{c}0.525 * * * \\
(21.78)\end{array}$ \\
\hline Lev & $\begin{array}{c}-0.038^{* * * *} \\
(-4.65)\end{array}$ & $\begin{array}{c}0.016^{* *} \\
(2.50)\end{array}$ & $\begin{array}{c}0.026^{* * *} \\
(4.41)\end{array}$ & $\begin{array}{c}0.022 * * * \\
(3.97)\end{array}$ \\
\hline Size & $\begin{array}{c}0.018^{* * *} \\
(11.09)\end{array}$ & $\begin{array}{c}-0.011^{* * *} \\
(-8.51)\end{array}$ & $\begin{array}{c}-0.009^{* * *} \\
(-7.43)\end{array}$ & $\begin{array}{c}-0.010^{* * *} \\
(-9.93)\end{array}$ \\
\hline Shrcr1 & $\begin{array}{c}0.000 * * * \\
(5.04)\end{array}$ & $\begin{array}{c}0.000 * * * \\
(3.57)\end{array}$ & $\begin{array}{l}-0.000 * \\
(-1.66)\end{array}$ & $\begin{array}{c}-0.000^{* * *} \\
(-5.44)\end{array}$ \\
\hline Director & $\begin{array}{c}0.006^{* * *} \\
(4.24)\end{array}$ & $\begin{array}{c}0.002 * * * \\
(2.61)\end{array}$ & $\begin{array}{l}-0.001 \\
(-1.42)\end{array}$ & $\begin{array}{l}-0.001 \text { * } \\
(-1.95)\end{array}$ \\
\hline Indep & $\begin{array}{c}0.080^{* *} \\
(2.20)\end{array}$ & $\begin{array}{l}0.008 \\
(0.43)\end{array}$ & $\begin{array}{l}-0.008 \\
(-0.36)\end{array}$ & $\begin{array}{c}-0.036^{* *} \\
(-2.14)\end{array}$ \\
\hline Duality & $\begin{array}{l}-0.005 \\
(-1.64)\end{array}$ & $\begin{array}{l}-0.003 * \\
(-1.74)\end{array}$ & $\begin{array}{l}0.001 \\
(0.73)\end{array}$ & $\begin{array}{l}-0.001 \\
(-0.58)\end{array}$ \\
\hline MB & $\begin{array}{l}0.005 * \\
(1.65)\end{array}$ & $\begin{array}{c}-0.005^{* * *} \\
(-3.20)\end{array}$ & $\begin{array}{l}0.001 \\
(0.77)\end{array}$ & $\begin{array}{c}0.012 * * * \\
(7.90)\end{array}$ \\
\hline PPE & $\begin{array}{c}-0.042^{* * *} \\
(-4.07)\end{array}$ & $\begin{array}{c}-0.021 * * * \\
(-3.37)\end{array}$ & $\begin{array}{l}-0.001 \\
(-1.35)\end{array}$ & $\begin{array}{l}-0.009 \\
(-1.55)\end{array}$ \\
\hline constant & $\begin{array}{c}-0.301^{* * *} \\
(-7.04)\end{array}$ & $\begin{array}{c}0.298^{* * *} \\
(9.71)\end{array}$ & $\begin{array}{c}0.163^{* * *} \\
(6.15)\end{array}$ & $\begin{array}{c}0.210^{* * * *} \\
(9.63)\end{array}$ \\
\hline Cluster & Yes & Yes & Yes & Yes \\
\hline FE & Yes & Yes & Yes & Yes \\
\hline $\mathrm{N}$ & 12,674 & 12,674 & 10,340 & 10,340 \\
\hline Adj_R2 & 0.134 & 0.411 & 0.047 & 0.155 \\
\hline
\end{tabular}

Note: ${ }^{* * *},{ }^{* *}$ and ${ }^{*}$ represent significant at $1 \%, 5 \%$ and $10 \%$ levels, respectively; The $t$ value is in brackets; the standard error is cluster-adjusted at the company level.

\subsubsection{Propensity Score Matching}

To ensure the randomness of the experimental group and the control group, we use the Propensity Score Matching (PSM) method to match the two groups. The first step isto perform a logit regression considering all the control variables from this study as corporate characteristic variables, and then use the predicted value as a matching score for one-to-one neighbor matching. The table in Appendix A lists the differences between the control group and the experimental group before and after matching. The test results show no significant difference between the variables after matching, which confirms that the PSM adopted for this study satisfies the common support assumption.

In the second step, the matched samples are regressed according to model (1), and the results are shown in Table 12. Among them, the significance of the Group's coefficient is slightly weakened, but it is still significant at the $5 \%$ level. The coefficient is even higher after PSM procedure, indicating the robustness of the conclusions in this paper. 
Table 12. Propensity score matching.

\begin{tabular}{|c|c|c|}
\hline & (1) & (2) \\
\hline & CSR & CSR2 \\
\hline Group & $\begin{array}{c}0.019 \text { ** } \\
(2.44)\end{array}$ & $\begin{array}{c}0.004 \text { * } \\
(1.81)\end{array}$ \\
\hline ROA & $\begin{array}{c}0.624^{* * *} \\
(25.94)\end{array}$ & $\begin{array}{c}0.999 * * * \\
(63.92)\end{array}$ \\
\hline Lev & $\begin{array}{c}-0.064^{* * *} \\
(-7.29)\end{array}$ & $\begin{array}{l}0.002 \\
(0.38)\end{array}$ \\
\hline Size & $\begin{array}{c}0.043^{* * *} \\
(16.95)\end{array}$ & $\begin{array}{c}-0.012 \text { *** } \\
(-10.62)\end{array}$ \\
\hline Shrcr1 & $\begin{array}{l}0.000 \\
(0.62)\end{array}$ & $\begin{array}{c}0.000 * * * \\
(7.48)\end{array}$ \\
\hline Director & $\begin{array}{l}0.003 \\
(1.59)\end{array}$ & $\begin{array}{c}0.003^{* * *} \\
(5.38)\end{array}$ \\
\hline Duality & $\begin{array}{c}-0.008^{* *} \\
(-2.06)\end{array}$ & $\begin{array}{c}-0.003 \text { ** } \\
(-2.02)\end{array}$ \\
\hline $\mathrm{MB}$ & $\begin{array}{c}-0.009^{* * *} \\
(-3.10)\end{array}$ & $\begin{array}{c}-0.003 * * \\
(-2.24)\end{array}$ \\
\hline PPE & $\begin{array}{c}-0.055^{* * *} \\
(-5.12)\end{array}$ & $\begin{array}{c}-0.019 * * * \\
(-4.09)\end{array}$ \\
\hline constant & $\begin{array}{c}-0.792 * * * \\
(-13.14)\end{array}$ & $\begin{array}{c}0.283^{* * *} \\
(11.23)\end{array}$ \\
\hline Cluster & Yes & Yes \\
\hline $\mathrm{FE}$ & Yes & Yes \\
\hline $\mathrm{N}$ & 18,805 & 18,805 \\
\hline Adj_R2 & 0.212 & 0.373 \\
\hline
\end{tabular}

Note: ${ }^{* * *},{ }^{* *}$ and ${ }^{*}$ represent significant at $1 \%, 5 \%$ and $10 \%$ levels, respectively; The $t$ value is in brackets; the standard error is cluster-adjusted at the company level.

\subsubsection{Heckman's Two-Step Procedure}

As the establishment of business groups may not be a random process, this could lead to sample selection problems. Therefore, we refer to the methods used by $[53,69]$. In the first-step probit regression, we calculated the inverse Mills ratio (Lambda) by adding the variables such as company size (Size) and the shareholding ratio of the largest shareholder (Shrcr1), fixed asset ratio (PPE), return on assets (ROA), total asset growth rate (Growth), company age (Age), and lagged variable (Group $\mathrm{t}_{\mathrm{t}-1}$ ). In the second step, the inverse Mills ratio is added to model one and the regression is performed again.

The results of Heckman's two-step regression are shown in Table 13. Column 1 presents the first step result, which shows significant positive relations between Group and its lagged variable Group $\mathrm{t}_{\mathrm{t}-1}$. In the second-step regression (Column 2 and Column 3 ), the coefficients of Group are positively significant at the level of $5 \%$ on both CSR measures. while the regression coefficient Lambda are not significant, it further confirms our conclusions are not bothered with severe sample selection problems. 
Table 13. Heckman's two-step method.

\begin{tabular}{cccc}
\hline & $\mathbf{( 1 )}$ & $\mathbf{( 2 )}$ & $\mathbf{( 3 )}$ \\
\hline Group & CSR & CSR2 \\
\hline Group & & $0.010^{* *}$ & $0.004^{* *}$ \\
Group & & $(2.13)$ & $(2.00)$ \\
Lambda & $6.35^{* * *}$ & & \\
& $(74.97)$ & 0.047 & -0.000 \\
Controls & & $(0.20)$ & Yes \\
Cluster & Yes & Yes & Yes \\
FE & Yes & Yes & Yes \\
$\mathrm{N}$ & Yes & Yes & 17,740 \\
\hline 17,740 & 17,740 & \\
\hline $\begin{array}{l}\text { Note: }{ }^{* * *} \text { and } \\
\text { error is cluster-adjusted at the company level. }\end{array}$ & &
\end{tabular}

\section{Discussion}

The results have both theoretical and practical implications. From the theoretical perspective, although many studies have examined the CSR strategy in multiple aspects, very few have accounted for organizational form or group factors that could act on the decision making and the implementation of CSR potentially, especially in emerging countries like China. Our study enriches the literature in the field of business groups and provides a more complete view about how CSR strategies are implemented within a business group. By revealing the possible paths that lead to the improvement of CSR, our results inform other future related researches to further take group factors into their considerations, especially in emerging economies. Additionally, our conclusions may contribute to SDGs literature in better understanding the role of business groups in tackling sustainable development in emerging markets.

Our study has the following policy implications. First, our data shows a considerable gap between the average CSR rating score and that of the top one. It indicates that even though CSR has gained much more attention in recent years, CSR performance of most companies in China still underperforms. We also find that group companies are well performed in almost every aspects of non-economic social responsibilities, which indicates that most independent companies are devoted to the pursuit of economic returns, but lack of corresponding sense of social responsibility. The implement of a CSR activity is merely to meet the basic requirement from the government, or a pretense for tunneling of the management [73].

Second, we have reconfirmed the role of internal capital markets in resource allocation for business groups in the perspective of CSR using robust empirical models. It reflects that an underdeveloped institutional environment and capital market lay a clamp on the development and decision making of a firm. Thus, governments in emerging economies should make progress constantly in enacting steps to strengthen external capital markets, create a sound economic environment which would enable enterprises to achieve a qualitative leap.

Our results also show that rent-seeking and corporate reputation mechanisms works in CSR assuming of group companies, which provides useful insights for policymakers and regulators on how they can further evaluate and enhance the CSR performances of firms from different organizational forms. Government could take advantage of this by offering preferential policies and direct favorable conditions to those leading companies, and in turn, actively guide and motivate the sense and responsibility of assuming CSR of the whole society.

This study inevitably has its limitations. The data used for this study was limited to business groups formed by A-share listed companies in China and does not cover the fulfillment of CSR in non-listed independent companies and non-group listed companies. This to a certain extent may have caused the study's results to have problems of 
endogeneity. Therefore, with the availability of sufficient data, future studies may further focus on whether the group attributes of non-listed companies affect the development and implementation of their CSR strategies. Additionally, the extent of the impact of the business groups' pyramid structure on the group companies' CSR performance is also worth exploring.

\section{Conclusions}

The main aim of this paper was to explore the whether the affiliation to a business group benefit the firm's CSR performance. In this regard, we investigate the impact of business groups as an organizational model on CSR, and systematically examine the mechanisms that cause the differences in CSR between group companies and independent companies. Specifically, we have further considered five aspects of CSR, namely shareholders' responsibility, employees' responsibility, consumers' responsibility, environmental responsibility and social welfare, in relation to group affiliation.

The results show that the members of business groups bear an average $4 \%$ higher in CSR rating scores. Their incentives for assuming higher CSR mainly operate through three mechanisms: internal capital markets, rent-seeking and corporate reputation. In particular, the rent-seeking and corporate reputation considerations account for about $8 \%$ of the improvement of CSR performance. Moreover, Group affiliated firms are more interesting in engaging in non-economic aspects of CSR instead of economic responsibilities.

Author Contributions: Formal analysis, X.H.; writing-original draft preparation, X.H. and Q.C.; methodology, X.J.; conceptualization, X.J. and W.L.; data curation, W.L. All authors have read and agreed to the published version of the manuscript.

Funding: This study was financially funded by the project of Beijing Philosophy and Social Science Foundation in 2016(16YJC045), named "Research on the influence mechanism of Beijing Science and technology finance network collaboration on enterprise innovation performance", project of the National Social Science Foundation in 2019(19BJL059) and the project of Beijing Union University in 2020(SK30202004), named "Impact of COVID-19 and economic policy response". This study was additionally supported by the academic research projects of Beijing Union College (No. XP202012).

Institutional Review Board Statement: Not applicable.

Informed Consent Statement: Not applicable.

Data Availability Statement: The data presented in this study are available on request from the corresponding author. The data are not publicly available due to privacy.

Acknowledgments: We would like thank Shi from School of International Trade and Economy, University of International Business and Economy and anonymous reviewers for their useful comments on methodology and language editing which have greatly improved the manuscript.

Conflicts of Interest: The authors declare no conflict of interest.

\section{Appendix A}

Table A1. Differences of two groups before \& after matching.

\begin{tabular}{|c|c|c|c|c|c|c|c|c|}
\hline \multirow{2}{*}{ Variables } & \multirow{2}{*}{ Sample } & \multicolumn{2}{|c|}{ Mean } & \multirow{2}{*}{$\begin{array}{c}\text { Difference } \\
(\%)\end{array}$} & \multirow{2}{*}{$\begin{array}{l}\text { Diff. Reduction } \\
\text { Rate (\%) }\end{array}$} & \multicolumn{2}{|c|}{$t$-test } & \multirow{2}{*}{$\begin{array}{l}\mathrm{V}(\mathrm{T}) / \\
\mathrm{V}(\mathrm{C})\end{array}$} \\
\hline & & Experimental & Control & & & $t$ & $p>|t|$ & \\
\hline \multirow{2}{*}{ CSR } & $\mathrm{U}$ & 22.866 & 22.642 & 13.7 & \multirow{2}{*}{94.9} & 2.05 & 0.041 & 1.01 \\
\hline & M & 22.866 & 22.855 & 0.7 & & 0.09 & 0.932 & 1.00 \\
\hline \multirow[b]{2}{*}{ ROA } & $\mathrm{U}$ & 0.017 & 0.034 & -31.4 & \multirow[b]{2}{*}{90.8} & -4.70 & 0.000 & 1.06 \\
\hline & M & 0.017 & 0.019 & -2.9 & & -0.33 & 0.739 & 0.89 \\
\hline \multirow{2}{*}{ Lev } & $\mathrm{U}$ & 0.469 & 0.469 & -0.1 & \multirow{2}{*}{-1865.5} & -0.02 & 0.985 & 1.13 \\
\hline & M & 0.469 & 0.464 & 2.4 & & 0.29 & 0.775 & 0.94 \\
\hline
\end{tabular}


Table A1. Cont.

\begin{tabular}{|c|c|c|c|c|c|c|c|c|}
\hline \multirow{2}{*}{ Variables } & \multirow{2}{*}{ Sample } & \multicolumn{2}{|c|}{ Mean } & \multirow{2}{*}{$\begin{array}{l}\text { Difference } \\
(\%)\end{array}$} & \multirow{2}{*}{$\begin{array}{c}\text { Diff. Reduction } \\
\text { Rate }(\%)\end{array}$} & \multicolumn{2}{|c|}{$t$-test } & \multirow{2}{*}{$\begin{array}{l}\mathrm{V}(\mathrm{T}) / \\
\mathrm{V}(\mathrm{C})\end{array}$} \\
\hline & & Experimental & Control & & & $t$ & $p>|t|$ & \\
\hline \multirow{2}{*}{ Shrcr1 } & $\mathrm{U}$ & 42.298 & 41.315 & 6.8 & \multirow{2}{*}{46.8} & 1.01 & 0.313 & 0.84 \\
\hline & M & 42.298 & 41.775 & 3.6 & & 0.43 & 0.669 & 0.75 * \\
\hline \multirow{2}{*}{ Director } & $\mathrm{U}$ & 8.993 & 9.621 & -35.1 & \multirow{2}{*}{95.7} & -5.08 & 0.000 & 0.81 \\
\hline & M & 8.993 & 8.966 & 1.5 & & 0.20 & 0.844 & 1.05 \\
\hline \multirow{2}{*}{ Indep } & $\mathrm{U}$ & 0.384 & 0.368 & 25.2 & \multirow{2}{*}{90.4} & 3.93 & 0.000 & 1.43 * \\
\hline & M & 0.384 & 0.382 & 2.4 & & 0.26 & 0.795 & 0.86 \\
\hline \multirow{2}{*}{ Duality } & $\mathrm{U}$ & 0.055 & 0.064 & -4.2 & \multirow[b]{2}{*}{-4.1} & -0.61 & 0.545 & \\
\hline & M & 0.055 & 0.065 & -4.3 & & -0.52 & 0.602 & \\
\hline \multirow{2}{*}{ MB } & $\mathrm{U}$ & 1.683 & 1.300 & 25.7 & \multirow{2}{*}{97.5} & 4.08 & 0.000 & 1.64 * \\
\hline & M & 1.683 & 1.693 & -0.7 & & -0.07 & 0.942 & 1.08 \\
\hline \multirow{2}{*}{ PPE } & $\mathrm{U}$ & 0.215 & 0.221 & -3.0 & \multirow{2}{*}{51.9} & -0.45 & 0.655 & 1.12 \\
\hline & M & 0.215 & 0.212 & 1.4 & & 0.17 & 0.864 & 1.08 \\
\hline
\end{tabular}

Note: * represent significant at $10 \%$ levels.

\section{References}

1. Chandler, A.D. Strategy and Structure: Chapters in the History of the Industrial Enterprise; MIT Press: Cambridge, MA, USA, 1990; Volume 120.

2. McWilliams, A.; Siegel, D. Corporate social responsibility and financial performance: Correlation or misspecification? Strateg. Manag. J. 2000, 21, 603-609. [CrossRef]

3. Bartkus, B.R.; Morris, S.A.; Seifert, B. Governance and corporate philanthropy: Restraining Robin Hood? Bus. Soc. 2002, 41, 319-344. [CrossRef]

4. Lioui, A.; Sharma, Z. Environmental corporate social responsibility and financial performance: Disentangling direct and indirect effects. Ecol. Econ. 2012, 78, 100-111. [CrossRef]

5. Oikonomou, I.; Brooks, C.; Pavelin, S. The effects of corporate social performance on the cost of corporate debt and credit ratings. Financ. Rev. 2014, 49, 49-75. [CrossRef]

6. Zhou, H.; Jian, L.; Li, G. Corporate social responsibility and credit spreads-An empirical study based on China's public companies. Account. Res. 2016, 5, 18-25.

7. Jia, X.; Liu, Y. External environment, internal resource, and corporate social responsibility. Nankai Bus. Rev. 2014, 17, 13-18.

8. Waldman, D.A.; Siegel, D.S.; Javidan, M. Components of CEO transformational leadership and corporate social responsibility. J. Manag. Stud. 2006, 43, 1703-1725. [CrossRef]

9. Khanna, T.; Rivkin, J.W. Estimating the performance effects of business groups in emerging markets. Strateg. Manag. J. 2001, 22, 45-74. [CrossRef]

10. Almeida, H.; Wolfenzon, D. Should business groups be dismantled? The equilibrium costs of efficient internal capital markets. $J$. Financ. Econ. 2006, 79, 99-144. [CrossRef]

11. Guillen, M.F. Business groups in emerging economies: A resource-based view. Acad. Manag. J. 2000, 43, 362-380.

12. Choi, J.J.; Jo, H.; Kim, J.; Kim, M.S. Business groups and corporate social responsibility. J. Bus. Ethics 2018, 153, 931-954. [CrossRef]

13. Dou, H.; Zhang, H.; Lu, Z. Supervision of business groups, major shareholders and over-investment. Manag. World 2014, 7 , 134-143.

14. Shao, J.; Liu, Z. Economic outcome of internal capital allocation for group: Evidence from Chinese group. Account. Res. 2008, 4, 47-53.

15. Almeida, H.; Park, S.Y.; Subrahmanyam, M.G.; Wolfenzon, D. The structure and formation of business groups: Evidence from Korean chaebols. J. Financ. Econ. 2011, 99, 447-475. [CrossRef]

16. Bertrand, M.; Mehta, P.; Mullainathan, S. Ferreting out tunneling: An application to Indian business groups. Q. J. Econ. 2002, 117, 121-148. [CrossRef]

17. Cheung, Y.L.; Rau, P.R.; Stouraitis, A. Tunneling, propping, and expropriation: Evidence from connected party transactions in Hong Kong. J. Financ. Econ. 2006, 82, 343-386. [CrossRef]

18. Dow, S.; McGuire, J. Propping and tunneling: Empirical evidence from Japanese keiretsu. J. Bank. Financ. 2009, 33, 1817-1828. [CrossRef]

19. Hopwood, B.; Mellor, M.; O’Brien, G. Sustainable development: Mapping different approaches. Sustain. Dev. 2005, 13, 38-52. [CrossRef]

20. Berrone, P.; Ricart, J.E.; Duch, A.I.; Bernardo, V.; Salvador, J.; Piedra Peña, J.; Rodríguez Planas, M. EASIER: An evaluation model for public-private partnerships contributing to the sustainable development goals. Sustainability 2019, 11, 2339. [CrossRef]

21. Udayasankar, K. Corporate social responsibility and firm size. J. Bus. Ethics 2008, 83, 167-175. [CrossRef]

22. Lu, X.W.; Liang, X.Y. Chinese private entrepreneurs' views on social responsibilities. Econ. Manag. J. 2009, 31, 64-68. 
23. Yun, J.; Gao, L. Corporate governance, organizational strategy and corporate social responsibility: Based on the perspectives of integration and evolution. China Ind. Econ. 2005, 11, 103-110.

24. Zhang, Z.; Jin, X.; Li, G. An empirical study on the intertemporal impact of the interaction between corporate social responsibility and financial performance. Account. Res. 2013, 8, 32-39.

25. Fei, X.; Li, C.; Zhou, S. Damage them all or a blessing in disguise?-Research on the reputation spillover effect of corporate social responsibility. Manag. World 2010, 4, 74-82.

26. Bae, K.H.; Kang, J.K.; Kim, J.M. Tunneling or value added? Evidence from mergers by Korean business groups. J. Financ. 2002, 57, 2695-2740. [CrossRef]

27. Bertrand, M.; Johnson, S.; Samphantharak, K.; Schoar, A. Mixing family with business: A study of Thai business groups and the families behind them. J. Financ. Econ. 2008, 88, 466-498. [CrossRef]

28. Khanna, T.; Palepu, K. Policy shocks, market intermediaries, and corporate strategy: The evolution of business groups in Chile and India. J. Econ. Manag. Strategy 1999, 8, 271-310. [CrossRef]

29. La Porta, R.; Lopez-de-Silanes, F.; Shleifer, A. Corporate ownership around the world. J. Financ. 1999, 54, 471-517. [CrossRef]

30. Huang, J.; Chen, X. Group management and corporate R\&D investment: An analysis based on the perspective of knowledge spillover and internal capital market. Econ. Res. 2011, 6, 81-93.

31. Wang, F.; Su, L. Is the internal capital market of Chinese listed companies effective?-Evidence from H-share listed companies. Account. Res. 2013, 1, 70-75.

32. Xin, Q.; Zheng, G.; Yang, D. Business groups, government control and investment efficiency. Financ. Res. 2007, 10, 123-142.

33. Morck, R.; Yeung, B. Agency problems in large family business groups. Entrep. Theory Pract. 2003, 27, 367-382. [CrossRef]

34. Claessens, S.; Djankov, S.; Lang, L.H. The separation of ownership and control in East Asian corporations. J. Financ. Econ. 2000, 58, 81-112. [CrossRef]

35. Zhong, H. Government intervention, insider control and corporate investment. Manag. World 2010, 7, 98-108.

36. Wang, P.; Zhou, L. Control power and ownership of controlling shareholders and corporate performance: Evidence based on China's listed companies. Financ. Res. 2006, 2, 88-98.

37. Liu, H. Length of the control chain and compensation contract of corporate senior management. Manag. World 2017, 95-112.

38. Quan, X.; Wu, S.; Wen, F. Management power, private benefits and salary manipulation: Empirical evidence from China's state-owned listed companies. Econ. Res. 2010, 45, 73-87.

39. Claessens, S.; Djankov, S.; Fan, J.; Lang, L. Disentangling the incentive and entrenchment effects of large shareholdings. J. Financ. 2002, 57, 2741-2771. [CrossRef]

40. Hillman, A.; Keim, G. International variation in the business-government interface: Institutional and organizational considerations. Acad. Manag. Rev. 1995, 20, 193-214. [CrossRef]

41. Chung, C.-N. Beyond Guanxi: Network contingencies in Taiwanese business groups. Organ. Stud. 2006, 27, 461-489. [CrossRef]

42. Khanna, T. The scope of alliances. Organ. Sci. 1998, 9, 340-355. [CrossRef]

43. Mio, C.; Panfilo, S.; Blundo, B. Sustainable development goals and the strategic role of business: A systematic literature review. Bus. Strategy Environ. 2020, 29, 3220-3245. [CrossRef]

44. United Nations. Transforming Our World: The 2030 Agenda for Sustainable Development. Resolution Adopted by the General Assembly on 25 September 2015. [Without Reference to a Main Committee (A/70/L.1)] 70/1. Available online: http:/ /www.un. org/en/development/desa/population/migration/generalassembly/docs/globalcompact/A_RES_70_1_E.pdf (accessed on 12 November 2019).

45. Sachs, J.D. From millennium development goals to sustainable development goals. Lancet 2012, 379, 2206-2211. [CrossRef]

46. Rupley, K.H.; Brown, D.; Marshall, S. Evolution of corporate reporting: From stand-alone corporate social responsibility reporting to integrated reporting. Res. Account. Regul. 2017, 29, 172-176. [CrossRef]

47. Hristov, I.; Chirico, A. The role of sustainability key performance indicators (KPIs) in implementing sustainable strategies. Sustainability 2019, 11, 5742. [CrossRef]

48. Schaltegger, S.; Lüdeke-Freund, F.; Hansen, E.G. Business cases for sustainability: The role of business model innovation for corporate sustainability. Int. J. Innov. Sustain. Dev. 2012, 6, 95-119. [CrossRef]

49. Guo, M.; He, L.; Zhong, L. Business groups and corporate social responsibility: Evidence from China. Emerg. Mark. Rev. 2018, 37, 83-97. [CrossRef]

50. Stein, J.C. Information production and capital allocation: Decentralized versus hierarchical firms. J. Financ. 2002, 57, 1891-1921. [CrossRef]

51. Chang, S.J.; Hong, J. Economic performance of group-affiliated companies in Korea: Intragroup resource sharing and internal business transactions. Acad. Manag. J. 2000, 43, 429-448.

52. Buchuk, D.; Larrain, B.; Muñoz, F.; Urzúa, F. The internal capital markets of business groups: Evidence from intra-group loans. J. Financ. Econ. 2014, 112, 190-212. [CrossRef]

53. He, J.; Mao, X.; Rui, O.M.; Zha, X. Business groups in China. J. Corp. Financ. 2013, 22, 166-192. [CrossRef]

54. Almeida, H.V.; Wolfenzon, D. A theory of pyramidal ownership and family business groups. J. Financ. 2006, 61, 2637-2680. [CrossRef]

55. Chung, C.-N. Markets, culture and institutions: The emergence of large business groups in Taiwan, 1950s-1970s. J. Manag. Stud. 2001, 38, 719-745. [CrossRef] 
56. Jiang, F.; Zhao, X.; Ma, J.; Liu, Q.; Li, H. Is enterprise environmental protection investment responsibility or rent-seeking? Chinese evidence. Environ. Dev. Econ. 2020, 1-19. [CrossRef]

57. Choi, M.; How, J.; Verhoeven, P. The Value of Political Connections in Business Groups (March 16, 2014). 2014 Financial Markets \& Corporate Governance Conference. Available online: https:/ / ssrn.com/abstract=2391623 (accessed on 14 February 2021).

58. Li, Z.; Tang, X.; Lian, Y. The puzzle of Chinese private enterprises' corporate social responsibility. Manag. World 2016, 9, 136-148.

59. Guan, K.; Zhang, R. Corporate reputation and earnings management: Effective contract concept or rent-seeking concept. Account. Res. 2019, 59-64.

60. Scott, W.R. Institutions and Organizations; Sage: Thousand Oaks, CA, USA, 1995; Volume 2.

61. Sroufe, R.; Gopalakrishna-Remani, V. Management, social sustainability, reputation, and financial performance relationships: An empirical examination of US firms. Organ. Environ. 2019, 32, 331-362. [CrossRef]

62. Brammer, S.; Brooks, C.; Pavelin, S. Corporate social performance and stock returns: UK evidence from disaggregate measures. Financ. Manag. 2006, 35, 97-116. [CrossRef]

63. Yu, T.; Lester, R.H. Moving beyond firm boundaries: A social network perspective on reputation spillover. Corp. Reput. Rev. 2008, 11, 94-108. [CrossRef]

64. Gopalan, R.; Nanda, V.K.; Seru, A. Affiliated firms and financial support: Evidence from Indian business groups. J. Financ. Econ. 2007, 86, 759-795. [CrossRef]

65. Shen, H.; Wang, L.; Wan, T. Can social responsibility reports and attestations send effective signals?-An analysis based on the theory of corporate reputation. Audit Res. 2011, 4, 87-93.

66. Chen, L.; Han, B.; Yang, X. Research on the interaction of corporate social responsibility and management turnover-Based on the empirical evidence of A-share listed companies. Account. Res. 2015, 8, 57-64.

67. Cai, W.; Ni, X.; Zhao, P.; Yang, T. Impact of business groups on innovation output: Empirical evidence from listed manufacturing companies. China Ind. Econ. 2019, 1, 137-155.

68. Cai, W.; Zeng, C.; Hu, Z. Business groups, monetary policy and cash holdings. Financ. Res. 2015, 114-130.

69. Almeida, H.; Campello, M. Financial constraints and investment-cash flow sensitivities: New research directions. In Proceedings of the Twelfth Annual Utah Winter Finance Conference, Salt Lake City, UT, USA, 12 December 2001.

70. Sobel, M.E. Asymptotic confidence intervals for indirect effects in structural equation models. Sociol. Methodol. 1982, 13, 290-312. [CrossRef]

71. Preacher, K.J.; Hayes, A.F. Asymptotic and resampling strategies for assessing and comparing indirect effects in multiple mediator models. Behav. Res. Methods 2008, 40, 879-891. [CrossRef]

72. Du, X.; Chen, Y.; Du, Y. Rent-seeking, political connections and "true" performance: Based on the empirical evidence of private listed companies. Financ. Res. 2010, 10, 135-157.

73. Gao, Y.; Chen, Y.; Zhang, Y. "Red scarf" or "green scarf": A study on the motivation of charitable donation of private enterprises. Manag. World 2012, 8, 106-114. 